\title{
INDYWIDUALISTYCZNE I SUPRAINDYWIDUALISTYCZNE PREDYKTORY OPTYMALNEGO ODDZIAŁYWANIA RESOCJALIZACYJNEGO NA SKAZANYCH W WARUNKACH WOLNOŚCIOWYCH
}

\begin{abstract}
Abstrakt: Spotkanie osiągające granice momentów dialogicznych, czyli sięgające głębi w komunikacji interpersonalnej, może być sytuacją tożsamościowo-twórczą, a zatem taką, w której tożsamość uczestników jest odgrywana, poznawana i doświadczana. Najistotniejszymi warunkami umożliwiającymi pełny dialog są: rodzaje relacji między uczestniczącymi stronami, uwaga i wzajemne zrozumienie oraz miłość. Relacje międzyludzkie różnią się ilością osób w nich uczestniczących, głębią, charakterem, intensywnością i mogą wskazywać na typ spotkania.

W nurcie antropologii filozoficznej Teilharda de Chardina Barbara Pasamonik przedstawia proces komunikacji jako relację o charakterze utylitarnym - nastawioną na osiągnięcie czegoś oraz jako relację personalistyczną, która ma na celu „spotkanie kogoś” (Pasamonik 1999, s. 102). W tej drugiej nie ma zamiaru czysto poznawczego, który redukowałby „Innego" do przedmiotu poznania; chodzi raczej o możliwość obcowania, otwierania się na drugiego człowieka, co jest możliwe tylko w przypadku związku opartego na odpowiedzialności.
\end{abstract}

Słowa kluczowe: dialog, spotkanie, dialog w resocjalizacji, proces komunikacji, sytuacja tożsamościo-twórcza, psychomanipulacja

\section{SPOTKANIE I DIALOG}

Odniesienie się do innego człowieka to dialog - inne imię miłości jako zaprzeczenie wrogości, nieufności, a praktykowanie odpowiedzialności za bliźniego. Spotkanie z pamięcią, przeszłością w środkach masowego przekazu może być doznaniem bolesnym, ale także inspirującym i wartościowym, choć nie prowadzi do żadnego 
„uwspólnienia pamięci”. Może stać się katalizatorem zmian w obszarze tożsamości jednostki, społeczeństwa i kultury (Jan Paweł II 2004a, s. 22).

W rozważaniach Martina Bubera jednostka to homo dialogus, istota dialogiczna - jedynie dzięki szczególnemu rodzajowi kontaktu z drugim człowiekiem, dzięki wypowiadaniu fundamentalnego słowa ja-ty i wejściu w dialogiczną relację staje się osobą i może być siebie świadomy (Buber 1992, s. 56). Obecność drugiej osoby jest warunkiem zaistnienia i urzeczywistniania się człowieczeństwa w pełnej niepowtarzalności i jednorazowości (Mader 1989, s. 374). Dialog jest zatem jednym $\mathrm{z}$ autentycznych sposobów bytowania jednostki, w której dokonuje się spełnienie osobowego bytu i zachodzi „przemiana w komunię”, we wspólnotę uczestników dialogu (Buber 1992, s. 211).

Sytuację zaistnienia relacji osobowej nazywamy spotkaniem i to w nim można odnaleźć treść ludzkiego życia. Wejście w relację - wymagające zaangażowania się całą istotą - przekształca człowieka $\mathrm{w}$,ja”, które jest realizowane jedynie w spotkaniu z drugą osobą, przez wejście w relację z „ty”.

Dialog między innymi w resocjalizacji wymaga zwrócenia się partnerów do siebie, otwarcia, szczerości, gotowości do wejścia w interakcje. Spotkanie z drugim człowiekiem, w którego centrum jest dialogiczna relacja, to sytuacja, kiedy jednostka zwraca się do drugiego jako do tej właśnie osoby w jej jednorazowości, konkretności i stara się z nią porozumieć za pośrednictwem słów, odrzucając próby wywarcia na partnerze wrażenia lub zdominowania go. To sytuacja ryzykowna, wymagająca zasadniczego zwrócenia się na drugiego, który może mocno zranić, i bycia gotowym na przemianę, po której osoba nie jest już tym samym podmiotem (Baran 1992, s. 113).

Dialogiczna narracja spełnia się w osobowym uobecnianiu: $\mathrm{w}$ „faktycznym przybliżeniu doświadczam przynależnego mi doświadczenia” i wówczas drugi człowiek staje się jaźnią wraz ze mną (Buber 1992, s. 137). Uobecnienie nie jest tożsame z empatią czy wglądem w innego i postawieniem się na jego miejscu. Jest to raczej proces poszerzania siebie oparty na zdolności realnego myślenia - wyobrażania sobie myśli i uczuć drugiej osoby „nie jako odebraną treść, lecz właśnie w rzeczywistości drugiego człowieka, to znaczy jako jego proces życiowy” (tamże, s. 136). Dzięki relacji dialogicznej osoba zostaje wzbogacona przez spotkanie z tym, co inne.

Dialog służy rozbudowaniu interakcji i zgodnie z poglądami Shoshany Steinberg i Dana Bar-Ona prowadzi do narracji składającej się z sześciu kategorii tworzących oś rozwoju tegoż dialogu (Steinberg, Bar-On 2002, s. 2). W pierwszym stadium dialogu, określonym mianem „mowy etnocentrycznej”, obie strony koncentrują się wyłącznie na sobie, nie słuchają się nawzajem, w dyskusjach pojawiają się stereotypowe sposoby patrzenia na partnera. Jest to $\mathrm{w}$ istocie etap dwóch równoległych monologów. W drugim stadium - „ataku” rozmówcy prezentują własne stanowisko 
i jednocześnie oskarżają się nawzajem i tym samym zwracają wyłącznie uwagę na siebie. Punktem zwrotnym narracji dialogicznej jest „uznanie różnic”, gdyż obie konkurujące ze sobą strony dostrzegają swoje odmienności i przyznają sobie prawo do odrębnych stanowisk, sądów wartościujących oraz uświadamiają sobie konieczność uważnego słuchania i podjęcia próby zrozumienia myśli partnera.

Kolejne stadium procesu porozumienia się stron na poziomie paradygmatu kultury i cywilizacji to „intelektualna dyskusja”, w której uczestnicy używają racji, słuchają się nawzajem, ustosunkowują się do przedłożonych argumentów, choć nie dzielą się jeszcze doświadczeniem i własnymi przeżyciami i nie opowiadają osobistych historii. Na tym etapie może dojść do kognitywnego zrozumienia drugiej strony.

Najważniejsze stadium rozwoju procesu dialogicznego - „momenty dialogiczne” - charakteryzuje się wzajemnością, równością, uważnym i nieosądzającym słuchaniem, dzieleniem się osobistymi doświadczeniami i biograficznymi wydarzeniami oraz uczuciami. Jest to kulminacyjny moment poznawczego i emocjonalnego zrozumienia partnera.

Zgodnie z wiedzą przekazaną przez Bubera dialogu nie da się zaplanować, a jedynie można stworzyć warunki sprzyjające jego zaistnieniu (Buber 1992, s. 172). Niezbędny w tym celu jest klimat akceptacji i bezpieczeństwa, umożliwiający wyzbycie się pozorów i otwarcie się na wiedzę drugiego partnera. Sytuacja powinna zapewnić równość uczestnictwa obu stron i umożliwiać zadzierżgnięcie bezpośrednich więzi między osobami. Współgrają z tym ustalenia psychologów społecznych dotyczące przeformułowanej hipotezy kontaktu i warunków skuteczności relacji międzygrupowych $w$ redukowaniu uprzedzeń i poprawie więzi między społecznościami (Pettigrew 1998, s. 72).

Spotkanie osiągające granice momentów dialogicznych, czyli sięgające głębi w komunikacji interpersonalnej, może być sytuacją tożsamościo-twórczą, a zatem taką, w której tożsamość uczestników jest odgrywana, poznawana i doświadczana. Najistotniejszymi warunkami umożliwiającymi dokonanie pełnego dialogu są: rodzaje relacji między uczestniczącymi stronami, uwaga i wzajemne zrozumienie oraz miłość. Relacje międzyludzkie różnią się ilością osób w nich uczestniczących, głębią, charakterem, intensywnością i mogą wskazywać na typ spotkania.

Nawiązując do antropologii filozoficznej Teilharda de Chardina, Barbara Pasamonik przedstawia proces komunikacji jako relację o charakterze utylitarnym nastawioną na osiągnięcie czegoś oraz jako relację personalistyczną, która ma na celu „spotkanie kogoś” (Pasamonik 1999, s. 102). W tej drugiej nie ma zamiaru czysto poznawczego, który redukowałby „Innego” do przedmiotu poznania; chodzi raczej o możliwość obcowania, otwierania się na drugiego człowieka, co jest możliwe tylko w przypadku związku opartego na odpowiedzialności. 
W analogiczny sposób Małgorzata Opoczyńska opisuje typ relacji interpersonalnych, określając je mianem relacji „pochyłej” i „poziomej” (Opoczyńska 2004, s. 169-177). Komunikacja „pochyła” wskazuje na spotkanie dokonujące się z perspektywy dwóch różnych płaszczyzn. Ktoś jest wyżej, a ktoś niżej. Jeden podmiot poznaje, a drugi jest poznawany. Nie jest to jednak poznanie charakterystyczne dla relacji „poziomej”, lecz pozbawione zaangażowania emocjonalnego zbieranie informacji o poznawanym.

Interakcja „pozioma” jest właściwością, która dysponując jedną płaszczyzną, prowadzi do rzeczywistego spotkania osób. W przeciwieństwie do relacji „pochyłej” relacja „pozioma” dokonuje się na płaszczyźnie akceptacji i zrozumienia, czyli miłości. Tylko interakcja oparta na tych wartościach może uchronić drugiego człowieka przed instrumentalnym traktowaniem wynikającym wyłącznie $\mathrm{z}$ chęci zdobycia wiedzy o nim. Tymczasem akceptacja, zrozumienie i odpowiedzialność stanowią jedyną właściwą płaszczyznę spotkania i dialogu, ale pod warunkiem, że wartości te są realne i tym samym nie zmierzają do zdominowania i podporządkowania jednostek (Gałdowa 2002, s. 228-229).

Pasamonik odnajduje w antropologii filozoficznej Teilharda de Chardina myśl, iż „miłość jest tą szczególną energią personalizacji, która nie stapia, nie homogenizuje, lecz różnicuje. Miłość różnicująca jest pogłębieniem wrażliwości, wzajemnym wzbogacaniem się i dopełnieniem" (Pasamonik 1999, s. 108). Tak rozumiana miłość w dialogu jest istotnie siłą tożsamościowo-twórczą.

Dla charakterystyki relacji „poziomej” bardzo cenna jest refleksja Ericha Fromma, iż

miłość jest produktywną formą więzi z innymi i z sobą samym. Zakłada ona odpowiedzialność, troskę, szacunek i wiedzę oraz pragnienie wzrostu i rozwoju osoby. Jest wyrazem więzi emocjonalnej miedzy dwiema istotami ludzkimi, realizowanej w warunkach zachowania własnej integralności (Wojtowicz 2005, s. 86).

Takie rozumienie miłości stanowi fundament relacji „poziomej”, a tym samym określa przesłanki i cel prawdziwego dialogu i spotkania, a także wskazuje na dwa z trzech możliwych kierunków działania. Spotkania będącego skierowaniem „ja” $\mathrm{w}$ stronę w drugiego człowieka i w kierunku samego siebie.

O szacunku do drugiego człowieka Fromm pisze, iż

nie jest strachem ani lękiem, oznacza on, zgodnie z rdzeniem wyrazu, zdolność do widzenia osoby takiej, jaka ona jest, do uświadomienia sobie jej indywidualności i wyjątkowości. Szacunek dla osoby nie jest możliwy bez jej poznania; 
troska i odpowiedzialność byłyby ślepe, gdyby nie były kierowane wiedzą dotyczącą indywidualnej jednostki (Fromm 200, s. 88).

Dialog, oprócz tego, że przemienia świadomość i stanowi punkt zwrotny w życiu człowieka, jest również sposobnością do uzyskania nowej wiedzy o sobie samym, a także do poznania wartości uobecnionych w spotkanym człowieku. Wówczas może zrodzić się nowa jakość więzi opartej na współprzeżywaniu poznanej wartości. Opoczyńska wyraźnie dotyka zakresu poznawania w dialogu i spotkaniu:

poznanie drugiej osoby, jakie staje się możliwe dzięki miłości, jest nie tylko współprzeżywaniem odkrytych w drugim osobowych cech, ale także ich współdokonywaniem. Może mieć ono różny wyraz: może być rozpoznaniem w sobie tych samych właściwości i stanów, które wcześniej odkryło się w drugim powiemy wówczas, że poznający, spotykając drugiego, odkrywa siebie, ale także może być „pójściem za” poznaną osobą i za odkrytymi w niej wartościami i stawaniem się jej zwolennikiem - poznający spotyka się z drugim człowiekiem, ale to spotkanie i dialog powoduje jego przemianę (Opoczyńska 2004, s. 153-154).

Mitologizacja przeszłości w komunikacji pedagogicznej, nadająca pamięci społecznej charakter normatywny, służy kształceniu tożsamości społecznej członków grupy, podtrzymywaniu jej spójności i pielęgnowaniu więzi grupowej. Maurice Halbwachs pisał: „społeczeństwo dąży do usunięcia ze swojej pamięci wszystkiego, co mogłoby dzielić jednostki, oddalać grupy od siebie i w każdej epoce zmienia ono swoje wspomnienia w ten sposób, by były zgodne ze zmiennymi warunkami społecznej równowagi”. Świadomość wspólnej przeszłości, dziejów przodków, taki sam zasób symboli i bohaterów, poczucie kontynuacji stanowią jeden z najważniejszych elementów grupowej tożsamości i podtrzymują „wspólnotę pamięci”, której członkowie w podobny sposób interpretują dzieje swej grupy, podziwiają te same autorytety i odczuwają obojętność do tych samych wrogów (Mader 1989, s. 131).

Pamięć społeczna o wspólnej przeszłości w procesie komunikowania umacnia prawo grupy do istnienia, jest skarbnicą wartości i wzorów do naśladowania przekazywanych jej członkom w okresie socjalizacji. Tworzy symboliczny język grupy, będący jednym z jej wyróżników, dostarcza też szereg innych znaków identyfikacyjnych i pozwala na wyróżnianie „swoich” i „obcych” dzięki swej roli interpretacyjnej, a także konstruowaniu i wykorzystywaniu stereotypowych obrazów grupy obcej oraz autostereotypów (Szacka 2003, s. 72).

Pedagogiczna treść komunikowania zawiera w sobie wymiar historyczno-kulturowy. Łączy on reinterpretację doświadczeń, zakładając wypracowanie pozytywnej identyfikacji z przestrzenią, kulturą, a także z ludźmi. Sprzyja temu przywiązanie 
do języka budujące poczucie odrębności i tworzenie przestrzeni dla dobrych doświadczeń i wydarzeń zakorzenionych w pamięci miejsca. Człowiek potrzebuje odwagi, determinacji i mądrości do utrzymania dialogu na poziomie tożsamości osobowej, społecznej i kulturowej, aby doprowadzić do rzeczywistego spotkania „dobrej woli, prawdy, triumfu sprawiedliwości i nadziei” (Jan Paweł II 2004b, s. 116).

\section{RESOCJALIZACJA W WARUNKACH WOLNOŚCIOWYCH JAKO SPOSÓB KOMUNIKOWANIA SIĘ WSPARTY NA PARADYGMACIE TOŻSAMOŚCI}

Pomagając osobie będącej w sytuacji trudnej, nie można traktować jej problemów zadaniowo, instrumentalnie, lecz należy potraktować sytuację jako spotkanie i nawiązanie dialogu między dwoma równorzędnymi partnerami. Jest to współdziałanie dwóch ekspertów: udzielającego interwencji w zakresie metod i sposobów postępowania oraz szukającego wsparcia specjalisty od własnego życia.

Dlatego też powodzenie udzielania pomocy zależy od zrozumienia przez uruchamiającego proces zmiany zachowania jednostki dynamiki powstałej sytuacji sprowadzającego się do uszanowania potrzeb, nadziei i możliwości osoby, która w przeszłości poszukiwała możliwości rozwiązania sytuacji trudnej.

Osoba będąca stroną procesu resocjalizacji powinna spotkać się z szacunkiem przynależnym każdej samodzielnej i pełnowartościowej jednostce, uznaniem własnej tożsamości i egzystencji, a także odrzucić świadomość, iż jest podmiotem poddającym się wyłącznie zewnętrznym działaniom i zabiegom.

Niewskazane są źle rozumiana opieka i litość, która w rzeczywistości nie zawiera szacunku, lecz przeciwnie - jest źle skrywaną pogardą, sposobem poniżenia. Prawdziwą pomocą w spotkaniu i dialogu resocjalizacyjnym jest organizowanie zmiany jako wsparcia dla samopomocy odwołującej się do własnych możliwości i dotychczasowych doświadczeń jednostki.

Oddziaływania pedagogiczne, jako sposób komunikowania się osób, osadzone na tożsamości gwarantują trwałość, skuteczność i efektywność tychże interwencji. Tożsamość to zestaw wartości i celów strukturalizujących życie jednostki (Bałandynowicz 2011, s. 25-53). Określana jest czterema wyznacznikami, wzajemnie powiązanymi, posiadającymi etyczny charakter, tj. wolnością, wyborem, odpowiedzialnością i zobowiązaniem. Jest ona związana z sensem życia człowieka i społeczeństwa.

Jednostka jest $\mathrm{w}$ wysokim stopniu formowana przez swoją przeszłość, przekazywane dziedzictwo i środowisko społeczne. Osoby znajdujące się w sytuacjach kryzysowych bywają często ofiarami wydarzeń i okoliczności niezależnych od nich i wymykających się spod ich kontroli. Równocześnie jednak są zawsze indywiduami mogącymi dokonywać wyboru i dokonują go ciągle. Pomimo że inni określili 
i zdecydowali o życiu jednostki, to jednak tylko ona sama może przeżyć to życie i dokonywać wszelkich decydujących o nim wyborów. Społeczna i osobowa tożsamość jest wartością etyczną, czyli definiującą sens życia jako odczuwanie samego siebie jako świadomie odpowiedzialnego za własne losy i wspólnotę społeczną. Utrata tożsamości jest zwyczajnym następstwem głębokiego psychologicznego i socjalnego kryzysu jednostki.

Dialog w resocjalizacji to pomoc w odtworzeniu osobowej i społecznej tożsamości. Jest zatem głównym zadaniem interwencji profesjonalnej, która polega na doprowadzeniu osoby do stanu gwarantującego samodzielną kontrolę nad własnym życiem i zintegrowanie ze społeczną wspólnotą. Metoda, dzięki której uzyskać można te pozytywne efekty, winna sprowadzać się do działania służącego potencjałom wzrastania i możliwościom rozwojowym jednostki. Nie można w oddziaływaniach resocjalizacyjnych obrać za punkt wyjścia słabości, braków, porażek, ale przeciwnie - należy wykorzystywać zasoby i potencjały człowieka ku wzrastaniu osobowo-społecznemu przez możliwości, szanse i ukryte zdolności (Konopczyński 1996, s. 165 i nast.).

Spotkanie i dialog w postępowaniu resocjalizacyjnym zmierzają w stronę kształtowania samooceny i samoświadomości społecznej jednostki. Samoświadomość jest stosunkiem osoby do samego siebie, stanem związanym z tożsamością osobową i własną osobowością. Sprowadza się do wzajemnej zależności między tymi dwoma procesami i stanowi pole walki własnego „ja” $\mathrm{z}$,ja” postrzeganym społecznie (Sobaczak 2004, s. 127).

Egzystencja osoby jest etycznie określona. Z tego wynika, iż jednostka może żyć dla innych, jeżeli w procesie wymiany społecznej naprawdę staje się sobą i w pełni realizuje siebie. We wzajemnych osobowych interakcjach musi istnieć dwustronny i dialektyczny stosunek, gdyż to on okazuje oblicze samooceny i samoświadomości społecznej oraz brak władzy, przewagi nad samym sobą oraz innymi ludźmi (Pytka 1995).

Oddziaływania resocjalizacyjne to proces odtwarzania zdolności i możliwości jednostki do samodzielnego kierowania swoim życiem oraz integrowania się na poziomie własnej autonomii, a nie we wspólnotach społecznych. Jest to możliwe przez dostęp do świata subiektywnego (osobowego), świata zewnętrznego (społeczeństwa) i świata obiektywnego (kultura). Być człowiekiem zintegrowanym to znaczy dysponować autonomią osobową, społeczną i kulturową, odpowiedzialną za dynamikę, strukturę i sens życia jednostki; dzięki niej tworzy się jej tożsamość, solidarność i zrozumienie (Malewska 1962, s. 28).

Jednostki wymagające specjalistycznych oddziaływań resocjalizujących to osoby, które w większości czują się niepotrzebne z powodu zróżnicowanych czynników społecznych odpowiedzialnych za ich proces dezintegracyjny. Charakteryzuje je 
poczucie bezsilności z powodu utraty kontroli nad codziennym środowiskiem. Te dwa czynniki - brak poczucia przydatności i utrata sensu życia - prowadzą do depresji jednostkowej oraz grupowej (Chałas 2003, s. 176).

Inne niekorzystne zjawisko, które często towarzyszy osobom wymagającym wsparcia i pomocy, to socjopatia jako forma egoizmu i obojętności na los drugiego człowieka. Rodzi się ona w atmosferze nadmiernego współzawodnictwa, zaspokajania potrzeb i popędów nawet za cenę skrzywdzenia innych oraz obojętności na sytuacje kryzysowe innych osób. Typowe formy zachowań socjopatycznych to karierowiczostwo, komercjalizacja i brak empatii w komunikacji społecznej. Ponadto wskazać można na zjawisko wiktymizacji, które osłabia procesy autoodpowiedzialności jednostki i zmierza ku oskarżaniu innych za wytworzone sytuacje traumatyzujące $w$ kontaktach społecznych. Jest to tendencja do oczyszczania siebie z winy i wstydu przez przerzucenie odpowiedzialności na innych ludzi. Stan nieufności i urazy wobec otoczenia społecznego stanowi przyczynę wszelkich frustracji i agresji (Urban 2000, s. 175).

Sytuacja kryzysowa, w której znajduje się jednostka, spowodowana jest zmianami w jej osobowości oraz w życiu, będącymi często następstwem przeżywanej traumy.

Czynniki wywołujące stan opresyjnej sytuacji przymusowej można podzielić na trzy grupy:

1) Wpływ uwarunkowań życia zbiorowości globalnej na pełnienie przez jednostkę pozytywnych ról społecznych, np. występujące zjawisko bezrobocia może utrudniać osobie pełnienie roli zawodowej.

2) Wpływ zmiany ról społecznych na osobowość jednostki, np. więzień opuszczający zakład karny stoi przed koniecznością znalezienia pracy i niejednokrotnie zdobycia nowego zawodu. Nawarstwiające się problemy związane z podejściem do nowych ról społecznych mogą powodować poczucie bezradności oraz powstanie stanu agresywno-lękowego.

3) Wpływ ponownego podziału ról społecznych, np. środowisko familijne niejednokrotnie nie akceptuje osoby, która stoi przed koniecznością nawiązania nowych więzi rodzinnych (Bott 1991, s. 172).

Stan kryzysu niekoniecznie musi stanowić doświadczenie negatywne, pogłębiające nieprzystosowanie społeczne. Podczas jego występowania bowiem pojawia się u jednostki silna motywacja do przezwyciężania problemów utrudniających poprawną socjalizację, co sprzyja pracy specjalisty z zakresu komunikacji resocjalizacyjnej. Aktywność jednostki w rozwiązywaniu trudnych sytuacji życiowych może przyczyniać się do rozwoju jej prospołecznej osobowości i nawiązywania pozytywnych interakcji społecznych (Bell 1999, s. 79). 
Faza reakcji na stany kryzysowe składa się z trzech etapów. Pierwszy to uświadomienie trudności wywołujących u jednostki napięcie emocjonalne, kiedy stara się ona samodzielnie zaradzić istotnym problemom życiowym. Drugi to wzrost napięcia i towarzyszący mu proces wewnętrznej dezintegracji spowodowany ewentualnymi niepowodzeniami. Ostatnim etapem reakcji na kryzys jest demonstrowanie postaw agresywnych i negatywistycznych wobec otoczenia społecznego postrzeganego jako źródło problemów życiowych. A zatem zasadniczym celem oddziaływania resocjalizującego jest:

1) zmniejszenie lęku jednostki przed otaczającą go rzeczywistością społeczną;

2) osłabienie poczucia bezradności i braku bezpieczeństwa;

3) mobilizowanie sił wewnętrznych oraz zasobów i potencjałów zewnętrznych do najkorzystniejszego rozwiązania sytuacji;

4) łagodzenie stanu napięcia i zniecierpliwienia jednostki nawarstwiającymi się problemami w jej poprawnym funkcjonowaniu społecznym.

Aby złagodzić stan opresyjny podopiecznego, osoba resocjalizująca powinna okazywać powszechną akceptację jego osoby, zrozumienie oraz uszanowanie zaistniałej trudnej sytuacji, w której podopieczny się znajduje. Temu celowi służy również udzielanie zainteresowanemu informacji o możliwych, alternatywnych rozwiązaniach problemów oraz praktycznych rad mających pomóc w przezwyciężaniu trudności (Pospiszyl 2008, s. 179).

Mobilizowanie sił wewnętrznych obejmuje szerokie wykorzystywanie w procesie resocjalizacji technik wspierających m. in. doradzania, psychoterapii podtrzymującej czy dyskusji refleksyjnej. Wspomaganie zewnętrzne zaś obejmuje pośrednie metody oddziaływań terapeutycznych wykorzystujących dostępne w społeczeństwie środki pomocy, takie jak: skierowanie do zakładu specjalistycznej opieki, pomoc materialna, postępowanie środowiskowe.

Ponieważ w przypadku podopiecznych reakcja na kryzys wyraża się w postawach agresywnych i negatywistycznych będących wynikiem długotrwałej dezintegracji potrzeb oraz nawarstwiających się trudności w środowisku społecznym, zmniejszenie stanów depresyjnych, socjopatycznych, lękowych, osłabienie poczucia bezradności i braku bezpieczeństwa stanowi cel interwencji resocjalizacyjnej w sytuacjach kryzysowych (Konopczyński 2009a, s.18).

Przed przystąpieniem do oddziaływania resocjalizacyjnego wychowawca powinien ocenić, jaki stopień motywacji do działań poprawczych reprezentuje podopieczny, czy łączą go pozytywne więzi z rodziną, a także jaki jest stopień mobilizacji sił wewnętrznych oraz zdolności własnych do nawiązywania pozytywnych kontaktów środowiskowych. Interwencja w sytuacji kryzysowej wymaga od specjalisty szybkiej i trafnie sformułowanej pełnej diagnozy psycho-pedagogicznej. 
Określenie czynników patogennych następuje przez analizę ważniejszych zachowań i postaw wychowanka oraz aktualnie stosowanych metod rozwiązywania istotnych życiowych spraw i problemów rzutujących na sferę postaw jednostki. Analiza ta jest niezbędna przy wyborze najbardziej skutecznych i efektywnych dla danego wychowanka metod mobilizowania sił wewnętrznych i zasobów oraz potencjałów zewnętrznych (Konopczyński 2009b, s. 79; Kieszkowska 2012).

W diagnozie uwzględnia się potrzeby wychowawcze jednostki w celu określenia potencjalnej równowagi emocjonalnej, do osiągnięcia której zmierza oddziaływanie resocjalizacyjne (Bernstein 1991). Podczas pracy z podopiecznym w sytuacji kryzysowej cele postępowania powinny być precyzyjnie określone i wyraźnie związane z istotą kryzysu tak, że ich osiągnięcie podczas oddziaływania poprawczego umożliwi poradzenie sobie z traumą. Jednostka pod wpływem czynników powodujących stan opresji może nie dowierzać, że zakładane cele postępowania resocjalizacyjnego będzie w stanie osiągnąć. Sytuacja taka może wywołać obniżenie motywacji do tego rodzaju aktywności. W przypadku powodzenia nawet drobnego przedsięwzięcia osoba poddana próbie bardzo często odzyskuje motywację i energię do dalszego współdziałania $\mathrm{z}$ wychowawcą.

Jeżeli przeważającym czynnikiem kryzysogennym są trudności wynikające z konieczności zmiany pełnionych przez jednostkę ról społecznych lub ponownego ich wyboru, to na pozytywne efekty wpływają trzy elementy. Po pierwsze, psychiczna i emocjonalna gotowość podopiecznego do pełnienia nowych ról społecznych, np. chęć podjęcia nauki w celu przekwalifikowania zawodowego. Po drugie, gotowość do zmiany społecznej wynikającej z podjęcia nowej roli w układach zbiorowych, np. zmiana środowiska sąsiedzkiego czy środowiska rówieśniczego. Ostatnim zaś czynnikiem jest zdolność asymilacji do nowych warunków społecznych potwierdzająca zaspokojenie potrzeb wychowawczych jednostki.

Długoterminowa praca resocjalizacyjna obejmuje opiekę zindywidualizowaną ze względu na zaburzenia psychiczne o podłożu organicznym lub somatycznym. Stany kryzysowe pojawiające się w tych przypadkach stanowią tylko część przyczyn determinujących psychospołeczne dysfunkcje jednostek. Dlatego przeciwdziałanie im, przy zastosowaniu metod i środków właściwych dla danej sytuacji, nie rozwiązuje istotnych spraw i problemów jednostki, które rzutują na sferę postaw człowieka (Bell 1999, s. 113).

Długoterminowa praca wspomagająca oddziałuje na trzy obszary problemowe związane z poprawnym funkcjonowaniem osoby w społeczeństwie. Po pierwsze, na zaburzenia osobowości, które implikują nieprzystosowanie społeczne. Ponadto na sytuacje, w których stopień dysfunkcji zachowania jednostki powoduje konieczność nawiązania ściślejszego związku z opiekunem i częstszych z nim kontaktów podczas postępowania resocjalizacyjnego. Dotyczy to skazanych charakteryzujących się 
trwałą utratą zdrowia, a nawet inwalidztwem, upośledzonych i chorych umysłowo. Ostatnim obszarem problemowym są trudne sytuacje życiowe, których rozwiązanie ze względu na ich istotę wymaga postępowania długoterminowego. Mogą je stanowić problemy mieszkaniowe, trudności finansowe związane z zabezpieczeniem materialnym rodziny, kiedy wydaje się, że podopieczny nie ma szans na znalezienie innej pracy niż niskopłatnej.

Ze względu na rozciągnięte w czasie oddziaływanie resocjalizacyjne opiekuna istotne znaczenie dla powodzenia tegoż procesu ma umiejętne podtrzymywanie motywacji jednostki do działań poprawczych oraz skupianie się na najważniejszych problemach utrudniających jej poprawne funkcjonowanie społeczne (Bartol 2005, s. 128; Kieszkowska 2012).

Motywacja osoby do działań poprawczych słabnie, gdy stan opresji, w którym się znalazła, ulega złagodzeniu i gdy sytuacja życiowa ulega poprawie. Dla podtrzymania motywacji skazanego podczas długofalowej pracy postpenitencjarnej istotne znaczenie ma wyrażenie przez opiekuna zrozumienia dla trudnej sytuacji życiowej podopiecznego. Sprzyjać to będzie określeniu najważniejszych problemów w poprawnym funkcjonowaniu jednostki w społeczeństwie $\mathrm{z}$ jego perspektywy życiowej (Wysocka 2008, s. 117). Ponadto czynnikiem rzutującym na stan motywacji będzie udzielenie podopiecznemu pomocy mającej na celu złagodzenie skutków ewentualnych niepowodzeń w czasie samodzielnych prób rozwiązywania przez niego problemów. Tak świadczona pomoc będzie obejmowała zastosowanie technik wspierających, takich jak zachęcanie skazanego do podejmowania dalszych przedsięwzięć, wyrażanie zaufania do jego zamiarów oraz pełna akceptacja jego osoby. W przypadkach, gdy jednostka dotknięta jest znaczną utratą zdrowia czy kalectwem lub nie jest w stanie zapewnić swojej rodzinie środków utrzymania, niezbędne będzie wykorzystanie pomocy materialnej. Może być ona świadczona bezpośrednio ze środków, którymi dysponuje opiekun, bądź za pośrednictwem działających w otoczeniu społecznym instytucji pomocowych.

Ostatnią okolicznością rzutującą na podtrzymanie motywacji u skazanego jest umiejętne rozbudzanie u niego nadziei na rozwiązanie problemów życiowych i pozytywne wykorzystanie zniecierpliwienia z powodu braku istotnych postępów w przezwyciężaniu trudności w adaptacji społecznej. W teorii pracy pomocowej obydwa czynniki - nadzieja i zniecierpliwienie - określone są mianem „stymulatorów motywacji do działań resocjalizacyjnych” (Deutschmann 2001, s. 79).

Oczywiście, złożoność niektórych problemów determinujących życie zbiorowości społecznej wyklucza ich rozwiązywanie w pracy długoterminowej. Na przykład kłopoty mieszkaniowe skazanego po opuszczeniu zakładu penitencjarnego ze względu na swoją istotę nie mogą być rozwiązane bez nakładu poważnych środków finansowych. Dlatego mogą one nie zostać rozwiązane jeszcze przez dłuższy 
czas. W tej sytuacji zniecierpliwienie i, realnie oceniając, nikła nadzieja na poradzenie sobie z trudnościami są obiektywnie uzasadnione, co powoduje niemożność ich wykorzystania $\mathrm{w}$ procesie podtrzymania motywacji. W takich przypadkach opiekunowi pozostaje użycie środków oddziaływania polegających na prostej interwencji pomocowej bądź stosowanie technik wspierających (Conklin 1992, s. 79).

Podczas wieloetapowej pracy podopieczny może odnieść wrażenie, że niewiele się zmieniło w sensie pozytywnym w jego sytuacji życiowej. Cel wychowawczy nawiązanego dialogu między opiekunem a podopiecznym może zostać $w$ takich okolicznościach zagubiony. Ponadto $\mathrm{w}$ trakcie długotrwałego postępowania resocjalizacyjnego występują dość liczne związki z różnymi sferami życia zbiorowości społecznej, co sprzyja rozproszeniu celów tegoż oddziaływania. Na przykład psychiczne dysfunkcje jednostki mogą wpłynąć na jakość interakcji z osobami będącymi członkami środowiska rodzinnego, pracowniczego czy sąsiedzkiego (Dolan 2004, s. 460). W takiej sytuacji opiekun powinien w pierwszej kolejności ustalić, jakie czynniki spowodowały rozproszenie wyznaczonych celów postępowania resocjalizacyjnego i rozważyć zagadnienia względnej doniosłości poszczególnych problemów dla sytuacji podopiecznego. Następnie należałoby ponownie sformułować najważniejsze zadania, które mogą zostać zrealizowane w danym momencie oddziaływania poprawczego, oraz na końcu ustalić sposób postępowania w celu rozwiązania najważniejszych problemów. To znaczy wyeliminować zachowania utrudniające jednostce poprawne funkcjonowanie w społeczeństwie (Goldberg 1991, s. 62).

\section{PRAKTYCZNE OBLICZE PROCESU RESOCJALIZACJI ŚRODOWISKOWEJ A REINTEGRACJA JEDNOSTKI ZE SPOŁECZEŃSTWEM}

Rodzinna terapia grupowa jest jedną z metod oddziaływania środowiskowego, która ma na celu zapewnienie wsparcia emocjonalnego osobie starającej się o ponowną adaptację społeczną. Przychylne usposobienie najbliższego otoczenia może pomóc jednostce w rozwiązywaniu istotnych życiowych spraw i problemów oraz pozytywnie wpływać na zmianę jej postaw. Niektóre osoby z otoczenia społecznego mogą mieć większy wpływ na jej pozytywne zachowanie, gdyż łączą je więzi ściślejsze od tych, jakie jest w stanie wypracować opiekun. Dlatego w określonym stopniu i zakresie mogą być one podmiotami współuczestniczącymi w procesie wychowywania osoby.

W ramach oddziaływania środowiskowego opiekun może korygować funkcjonowanie podstawowych kręgów środowiskowych jednostki przez wpływanie na stosunki panujące wewnątrz grupy. Istotą rodzinnej terapii grupowej jest 
modyfikowanie lub zmiana układu więzi rodzinnych, jeżeli stanowią one, ze względu na panujące wewnątrz grupy interakcje dysfunkcjonalne, przyczynę trudności $\mathrm{w}$ readaptacji społecznej osoby.

Rodzina jest układem społecznym łączącym jednostkę ze zbiorowością globalną. Jednocześnie jest czymś więcej niż tylko strukturą grupującą autonomicznie ludzi. Rodzina stanowi system wzajemnego oddziaływania jej podmiotów, którego celem jest utrzymanie wewnętrznej spójności grupy w obszarze wpływów środowiskowych i zapewnienie rozwoju osobowości jej członków. Interakcje między podmiotami grupy rodzinnej nakładają się wzajemnie tak, że wydają się być nierozerwalne, szczególnie w przypadku dzieci i młodocianych.

Konflikt jednostek wytwarza kryzys w rodzinie, jeszcze bardziej pogarszający ich trudną sytuację, zaś konflikt w rodzinie generuje napięcie między jednostkami, co z kolei pogłębia dysfunkcyjność grupy. Nawet jeśli poszczególni członkowie rodziny nie uczestniczą bezpośrednio w dysfunkcji zachowania podopiecznego, to jednak wpływa ona negatywnie na wszystkie podmioty w grupie. Pozytywna zmiana układu więzi rodzinnych osiągnięta w czasie terapii grupowej oznacza, że został przyjęty przez wszystkich członków rodziny konsensus, z którego wynika akceptacja osoby w grupie. Dlatego ewentualne blokowanie przez jednostkę działań mających prowadzić do poprawy, które czasem zdarza się w terapii indywidualnej, nie ma miejsca w przypadku terapii rodzinnej.

Celem takiej terapii jest przygotowanie rodziny do powrotu zresocjalizowanej osoby, a w przypadku zaburzenia więzi grupowych - pomoc w eliminowaniu interakcji dysfunkcjonalnych. Zadania te mogą zostać osiągnięte przez:

1) Usprawnienie form wzajemnej komunikacji między wszystkimi członkami rodziny. Niejasność i niezrozumiałość przekazywanych informacji jest typowym zjawiskiem występującym w rodzinach o zaburzonych interakcjach grupowych (Morris 1995, s. 79). Na niezrozumiałość i niejasność przekazu wpływają:

a) tendencja do generalizowania zachowań jednostki. Na podstawie pojedynczego incydentu czy wyrażonej często w konfliktowej sytuacji opinii zostają sformułowane wnioski dotyczące postaw i zachowania określonej osoby. Takie przesadne uogólnienia stanowią wyraz funkcjonujących w danej zbiorowości niekorzystnych stereotypów postępowania;

b) istnienie we wzajemnej komunikacji niedomówień, wynikających nie tylko z całkowitego pominięcia określonych wydarzeń i faktów, ale także z częściowej i wybiórczej ich relacji;

c) brak potrzeby rozmowy. Może ona być umotywowana okolicznościami, w których jednej ze stron nie odpowiada prowadzenie rozmowy 
bądź do wzajemnej komunikacji wnosi ona elementy tego, co ją aktualnie absorbuje, a nie jest bezpośrednio powiązane $\mathrm{z}$ omawianym zagadnieniem. W każdej tego typu sytuacji wzajemne komunikowanie się członków grupy jest zaburzone;

d) niekonsekwentne przekazywanie wiadomości. Odbiorca informacji musi określić, jaką wagę przypisać poszczególnym elementom wypowiedzi, aby właściwie ukształtować swoją reakcję.

2) Eliminację występujących w osobowości jednostki zaburzeń emocjonalnych przejawiających się w wyrażaniu własnych potrzeb i uczuć.

3) Udzielenie pomocy w ustaleniu odpowiedniego podziału ról pełnionych $\mathrm{w}$ rodzinie, odpowiadających zajmowanej przez jednostkę pozycji społecznej i jej wiekowi.

4) Popieranie niezależności jednostki i swobodnego rozwoju jej osobowości w ramach funkcji, które pełni ona w środowisku rodzinnym (Marsden 1969).

Rozwinięcie efektywnych form wzajemnego przekazywania informacji jest niezbędne dla:

1) identyfikacji rzeczywistych problemów stanowiących przyczynę złego funkcjonowania rodziny, a nie okoliczności, które poszczególne jednostki uważają za powód zaburzeń układów grupowych;

2) uświadomienia członkom rodziny podopiecznego występowania interakcji dysfunkcjonalnych w grupie i udziału każdego z nich w tej dysfunkcjonalności;

3) udzielenia skutecznej pomocy w eliminowaniu niekorzystnych stereotypów postępowania.

Opiekun powinien zdobyć zaufanie wszystkich członków rodziny podopiecznego, co pozwoli ustalić plan współdziałania z nimi w procesie resocjalizacji.

Cele terapii grupowej prowadzonej $\mathrm{w}$ ramach procesu resocjalizacji, środki i metody służące ich osiągnięciu mają wiele wspólnego ze strategią indywidualnego oddziaływania kuratora sądowego na skazanego w procesie readaptacji społecznej (Jordan 1992, s. 11). Techniki terapeutyczne, takie jak: psychoterapia podtrzymująca, zachęcanie podopiecznego do podejmowania samodzielnych działań poprawczych, przejawianie postawy akceptującej możliwości rozwojowe jednostki oraz doradzanie, są szczególnie przydatne w początkowej fazie odnawiania więzi rodzinnych, które zostały osłabione podczas długotrwałej izolacji osoby w zakładzie karnym. Działania kontrolne podejmowane przez członków rodziny są mniej uciążliwe dla osoby uczestniczącej w procesie resocjalizacji niż bezpośrednia kontrola opiekuna. 
Dyskusja refleksyjna jest powszechnie stosowaną metodą w oddziaływaniu grupowym. Pozwala ona ocenić, w jakim stopniu doświadczenia wyniesione z wcześniejszych stadiów rozwojowych rodziny wpływają na jej aktualną sytuację.

Psychoterapia wentylująca, zastosowana w rodzinnej terapii grupowej, ma na celu stworzenie fizycznych i emocjonalnych warunków do ujawnienia przez poszczególnych członków grupy przyczyn zaburzeń więzi rodzinnych. Umożliwia ona członkom grupy określenie z perspektywy trudności w poprawnym funkcjonowaniu rodziny.

Wkładem opiekuna w tym procesie jest dostarczenie grupie rodzinnej własnych interpretacji jej głównych problemów związanych z:

- zaburzeniem komunikacji wewnątrzgrupowej,

- trudnościami w pełnieniu odpowiednich ról rodzinnych,

- utrzymaniem niezbędnej niezależności jednostki w grupie,

- udziałem każdego z członków rodziny w dysfunkcjonalnych interakcjach,

- eliminowaniem niekorzystnych stereotypów postępowania,

- współodpowiedzialnością wszystkich członków grupy za to, co się dzieje w interakcji rodzinnej,

- niezbędnym samookreśleniem się każdej jednostki umożliwiającym dostateczną indywidualizację i tolerancję wewnątrz grupy,

- niedostatecznym wyrażaniem potrzeb grupowych oraz indywidualnych (Konopczyński, Ambrozik 2009, s. 120).

Opiekun w czasie spotkań grupowych wpływa zarówno na jednostkę, jak i na pozostałych członków jego rodziny. Oddziaływanie terapeutyczne następuje przez komentowanie postaw i zachowań osoby w interakcjach rodzinnych. Dotyczy ono tak negatywnych, jak i pozytywnych form aktywności podopiecznego, często pojawia się dezaprobata dla jego negatywnych postaw. Nigdy jednak opiekun nie może pozwolić podczas grupowej terapii rodzinnej na jakąkolwiek formę osądzania osoby wychowywanej w warunkach procesu resocjalizacji.

Pomijając fakt, że grupy czy zbiorowości nie zawsze mają rację, przyczyny zaburzenia więzi rodzinnych mogą równie dobrze wynikać z dysfunkcji osobowościowych jednostki, jak i z negatywistycznych postaw określonych członków grupy (rodzina może nie akceptować osoby, pogłębiając w ten sposób patologię więzi rodzinnych). Oddziaływanie opiekuna na jednostkę w grupie rodzinnej stwarza możliwość wykorzystania do celów wychowawczych napięć emocjonalnych występujących między jej członkami. Wychowawca, przedstawiając grupie własne interpretacje przyczyn konfliktowej sytuacji, może w większym stopniu, niż to ma miejsce $\mathrm{w}$ indywidualnym przypadku, wykorzystać konfrontację różnych poglądów i opinii członków rodziny dotyczących przyczyn kryzysu. 
Nie można zapominać o tym, że w czasie rodzinnego oddziaływania wychowawczego każda jednostka stara się bronić zajmowanej przez siebie pozycji w grupie. Nie rezygnuje z takiej postawy nawet w sytuacji, gdy nie zaspokaja ona jej oczekiwań. Stara się wtedy uzyskać satysfakcję poza kręgiem rodzinnym, traktując jednak zajmowaną w nim pozycję jako coś, co jest atrybutem jej autonomii. W tej sytuacji atakowanie przez opiekuna tak manifestowanych postaw może doprowadzić do zerwania już osłabionych więzi łączących jednostkę z rodziną, a w efekcie do skierowania całej energii na sprawy pozarodzinne.

Środkiem wychowawczym pozwalającym wychowawcy uniknąć bezpośredniego konfliktu z jednostką jest przedstawienie rodzinie własnych interpretacji zachowań poszczególnych jej podmiotów. Zachowania i przyjmowane postawy mogą mieć pozytywny lub negatywny odbiór społeczny i jako takie kształtują sferę więzi rodzinnych, stanowiąc o poprawnym lub patologicznym funkcjonowaniu grupy. Indywidualne poglądy i opinie członków grupy skonfrontowane $\mathrm{z}$ interpretacjami opiekuna mogą stanowić przesłankę do pozytywnej zmiany w funkcjonowaniu tego środowiska. Ewentualne wsparcie udzielone wychowawcy przez część grupy może on wykorzystać w celu przekonania pozostałych członków do swoich poglądów.

Osiągnięta podczas rodzinnej terapii grupowej pozytywna rewizja dysfunkcjonalnych interakcji i więzi rodzinnych służy wykorzystaniu wewnętrznych sił rodziny dla wsparcia wysiłków osoby w jej readaptacji społecznej.

Metody stosowane w rodzinnej terapii grupowej są bardzo zbliżone do środków oddziaływania stanowiących narzędzie opiekuna w pracy z wychowankiem. Jednakże ze względu na specyfikę postępowania grupowego nie mogą one być automatycznie stosowane w terapii rodzinnej. Biorąc pod uwagę jej cele, resocjalizator, stosując metodę indywidualnych przypadków, musi pamiętać o tym, aby:

1) utrzymywać ukierunkowanie oddziaływania poprawczego na interakcje rodzinne, pomocniczo tylko stosować bezpośredni wpływ na jednostkę;

2) unikać nadmiernego identyfikowania się z jednym z członków rodziny;

3) zmiany postaw i zachowań jednostki ukierunkowywać tak, aby stanowiły one wzmocnienie więzi rodzinnych;

4) wykorzystywać pozytywny wpływ członków grupy na kształtowanie prospołecznej osobowości skazanego;

5) zachowywać przez cały czas trwania rodzinnej terapii grupowej bezstronność w stosunku do wszystkich jej podmiotów (Reid, Shyne 1997, s. 121).

Nie oznacza to, że w uzasadnionych celami postępowania resocjalizacyjnego okolicznościach opiekun nie może wesprzeć swoim autorytetem postaw reprezentowanych przez część grupy. Tak jak wspomniałem wcześniej, wykorzystanie konfrontacji opinii głoszonych przez poszczególnych członków rodziny sprzyja ustaleniu, która część grupy (lub która osoba) reprezentuje pozytywne wzory zachowań. 
Rodzinna terapia grupowa w ramach procesu resocjalizacji może być zastosowana, gdy:

- członkowie rodziny, pomimo trudności w poprawnym funkcjonowaniu, chcą nadal tworzyć wspólnotę;

- jednostki w grupie są gotowe przyjąć do wiadomości fakt występowania w rodzinie dysfunkcjonalnych interakcji i uświadomić sobie udział każdej z nich w tej dysfukcjonalności;

- złe funkcjonowanie rodziny determinowane jest zaburzeniami w sferze interakcji, a nie patologią jednostki.

Rodzinna terapia grupowa okazuje się nieskuteczna w sytuacji, gdy nastąpił zanik więzi rodzinnych, a w związku z tym motywacja do działań poprawczych jest niewielka i energia rodziny, jako całości, skierowana zostaje na pozarodzinne kręgi środowiskowe (James, Gilland 2009, s. 121). Jeżeli zaś dane stosunki rodzinne charakteryzuje dystans emocjonalny, a społeczność rodzinna rządzi się specyficznymi normami podkulturowymi, co powoduje nieuczciwość we wzajemnych stosunkach, opiekun powinien stosować oddziaływanie wychowawcze oparte na strategii indywidualnych przypadków. Zmierza ono do eliminacji negatywistycznych postaw i zachowań jednostki w grupie. Dopiero po osiągnięciu pewnego zaawansowania tego procesu resocjalizator powinien poddać ocenie funkcjonowanie wychowanka w rodzinie. Zależnie od ujawnionych potrzeb wychowawczych opiekun kieruje swoje oddziaływanie bądź na podopiecznego w rodzinie, bądź na kształtowanie poprawnej interakcji pozostałych członków grupy, w tym wzajemnych stosunków $\mathrm{z}$ tą osobą. W takich okolicznościach w pierwszej fazie oddziaływania poprawczego opiekun używa środków właściwych dla pracy z jednostką lub też stara się włączyć osobę w interakcje rodzinne.

To alternatywne postępowanie nie przekreśla możliwości wykorzystania procesów grupowych już na etapie oddziaływania terapeutycznego na podopiecznego. Nie wyklucza również możliwości wykorzystania rodzinnej terapii grupowej w sytuacji, gdy najistotniejsze problemy życiowe jednostki zostaną rozwiązane w czasie oddziaływania indywidualnego.

W rodzinnej terapii grupowej, podobnie jak w pracy z wychowankiem, opiekun będzie starał się sformułować diagnozę patologii rodziny. Stanowić ona będzie podstawę do wspólnego z rodziną określenia celów poprawczych możliwych do zaakceptowania przez obie strony procesu wychowawczego, a także wybrania najefektywniejszych, w stosunku do istoty problemu, środków postępowania.

Istota diagnozy formułowanej podczas rodzinnej terapii grupowej polega na tym, że stanowi ona wynik ukierunkowania oddziaływania wychowawcy na interpretację jakości interakcji rodzinnych i zajmowanych podczas ich przebiegu postaw przez poszczególnych członków grupy. Diagnozę taką kształtują m.in. dane dotyczące: 
a) czasu zawarcia przez podopiecznego związku małżeńskiego, określającego moment zawiązania rodziny,

b) funkcji rodzicielskiej jako rodzajowego uzupełnienia istniejących więzi rodzinnych,

c) ważnych wydarzeń wpływających na ogólną sytuację rodziny,

d) warunków socjalno-bytowych rodziny. Gdy sytuacja materialna rodzin ulega systematycznemu pogorszeniu tak, że w efekcie plasuje je poniżej minimum ekonomicznego, może ona rzutować na kształtowanie się agresywnych postaw członków grupy (George, Wilding 1992, s. 272).

Niezapewnienie przez rodzinę właściwych warunków materialnych sprzyja nieprawidłowemu przebiegowi procesu socjalizacji jednostki. Stan ubóstwa rodzin osób resocjalizowanych wywiera destruktywny wpływ na podejmowanie przez ich członków wyborów, jeśli chodzi o cele, zadania i szanse życiowe.

Niedostatek i bieda w rodzinach pokoleniowych stwarzają sprzyjające warunki do wczesnego opuszczania wspólnego gospodarstwa domowego na skutek braku satysfakcji materialnych, niezbędnych zwłaszcza w okresie adolescencji młodzieńczej. Prowokują również do podejmowania wyborów łatwych, agresywnych, często antyprawnych $\mathrm{w}$ celu powiększenia stanu posiadania i zaspokojenia potrzeb materialnych. Skromne warunki bytowe rodzin pogarsza często trudna sytuacja mieszkaniowa. Większość z nich mieszka w warunkach przeciętnych lub zdecydowanie złych.

$\mathrm{W}$ procesie diagnozowania opiekun interpretuje wzory porozumiewania się (komunikacji) w rodzinie, jakość pełnionych w niej ról, sposoby wzajemnego wyrażania uczuć (bliskość dystansu emocjonalnego członków rodziny), potrzeby wychowawcze jej członków oraz lęk przed zmianami, z których to wynika przyjmowanie przez jednostki postaw obronnych w interakcjach rodzinnych. Informacje zebrane przez opiekuna $w$ czasie oddziaływania terapeutycznego na rodzinę podopiecznego oraz wnioski wypływające z interpretacji postaw jej członków i interakcji grupowych służą określeniu najważniejszych przyczyn złego funkcjonowania rodziny. I tak m.in.:

a) zdezorganizowanie rodziny osoby może stanowić następstwo odbywania przez nią długoletniej kary pozbawienia wolności;

b) rozbicie rodziny jest często związane ze spadkiem autorytetu osoby jako głowy rodziny. Fakt, że weszła ona w konflikt z prawem, obniża jej autorytet i może stanowić przesłankę do podejmowania przez nią działań antyprawnych, pogłębiających patologię grupy;

c) dysfunkcjonalność rodziny może wypływać z dezintegracyjnego zachowania, m.in. z nietrzeźwości jednego lub obojga rodziców (Willmott, Young 2001, s. 211); 
d) rozkład więzi w rodzinie może stanowić następstwo trwałej utraty zdrowia, a nawet inwalidztwa podopiecznego będącego skutkiem autodestrukcyjnych czynności podejmowanych w zakładzie karnym.

Alkoholizm może być powodem braku zainteresowania sprawami rodziny, systematycznych awantur, bicia i innych form znęcania się nad członkami rodziny, wynoszenia $\mathrm{z}$ domu różnych przedmiotów w celu uzyskania środków na zdobycie alkoholu, demolowania mieszkania i niszczenia mienia domowego. Alkoholizm członków rodziny osoby połączony z degradacją alkoholową osobowości jednostki (psychozy alkoholowe, znaczny stopień agresji w stosunku do domowników, postępujące ubóstwo życia duchowego, stany depresyjne i lękowe) stanowi przyczynę jej umieszczenia w zamkniętych ośrodkach odwykowych, poradniach lub szpitalach.

Utrwalenie wzorów nadużywania alkoholu i kultywowanie wynikających z niego norm obyczajowych w rodzinach osób resocjalizowanych może powodować ich powrót do przestępstwa. Z czynów zagrożonych sankcją karną jednostki dotknięte chorobą alkoholową popełniają najczęściej przestępstwa chuligańskie i przestępstwa przeciwko mieniu dokonane $\mathrm{z}$ chęci zysku.

Fizyczna autodestrukcja (samookaleczenia) podyktowana wzorami zachowań subkultury więziennej pogłębia zaburzenia funkcjonowania sfery psychospołecznej i somatycznej osoby. Determinuje nieprzystosowanie społeczne podopiecznego i utrudnia podejmowanie oraz pełnienie podstawowych ról w zbiorowości globalnej. Kalectwo osoby może w znacznym stopniu utrudniać podjęcie przez nią zatrudnienia. Fakt niedostatecznego zaspokajania podstawowych potrzeb materialno-bytowych własnej rodziny, na skutek niemożności podjęcia pracy zarobkowej, może doprowadzić do dysfunkcji interakcji grupowych, a w efekcie do pogłębienia patologii rodziny.

Przez to, że najbliższe więzi emocjonalne łączą jednostkę z rodziną, stanowi ona najefektywniejszą grupę modelującą zachowania i postawy społeczne osoby podejmującej wysiłki ponownego włączenia się w poprawne funkcjonowanie społeczne. Ponieważ znaczna część osób pochodzi z rodzin zdezorganizowanych, niezbędne jest oddziaływanie opiekuna zmierzające do poprawy dysfunkcjonalnych interakcji grupowych. W tej sytuacji najbardziej efektywnym, ekonomicznym i zarazem szybkim sposobem udzielenia pomocy jest rodzinna terapia grupowa. Podstawowym narzędziem wychowawcy w czasie pracy z podopiecznym $\mathrm{w}$ procesie resocjalizacji jest przeprowadzenie wywiadu z osobą poddaną próbie. Celem wywiadu jest wspólne określenie przez opiekuna i podopiecznego potrzeb wychowawczych osoby, najważniejszych przyczyn utrudniających bezkonfliktowe pełnienie ról społecznych oraz przyjęcie planu postępowania poprawczego. Dopiero w ramach tak przyjętej strategii dochodzi do rozwiązywania istotnych życiowych spraw i problemów rzutujących na sferę postaw społecznych osoby opuszczającej zakład karny. 
W rodzinnej terapii grupowej wywiad przybiera formę uzyskiwania przez opiekuna informacji od członków rodziny dotyczących ważnych faktów i wydarzeń $\mathrm{z}$ dotychczasowego funkcjonowania środowiska rodzinnego. Rzutują one bezpośrednio na sferę postaw i zachowań członków rodziny. Następnie resocjalizator dokonuje własnej interpretacji zebranych informacji i konfrontuje je z opiniami poszczególnych członków grupy.

Ten sposób postępowania sprzyja wspólnej identyfikacji najważniejszych przyczyn zaburzeń interakcji rodzinnych i określeniu sposobu postępowania poprawczego. Ponieważ przestępcy, a zwłaszcza recydywiści, charakteryzują się znacznymi zaburzeniami funkcjonowania w sferze psychospołecznej i somatycznej, powstaje konieczność stosowania wobec nich terapeutycznych form oddziaływania. Stąd wywiad, stosowany w pracy $\mathrm{z}$ wychowankiem i podczas oddziaływania na najbliższe środowisko jednostki, teoria pracy pomocowej określa mianem „wywiadu terapeutycznego".

Podczas procesu resocjalizacyjnego opiekun posługuje się tak zwanymi niskimi poziomami psychoterapii (psychoterapia wentylująca i podtrzymująca, doradzanie, rozmowa refleksyjna itp.). Jednakże w przypadku niektórych grup skazanych stopień dysfunkcji osobowościowych jest tak wysoki, że wymaga zastosowania oddziaływań specjalistycznych. Na przykład stwierdzony u podopiecznego alkoholizm połączony z degradacją alkoholową wymaga leczenia w szpitalach psychiatrycznych lub ośrodkach i poradniach odwykowych. Znaczny stopień utraty zdrowia (w wyniku podejmowanych czynności autodestrukcyjnych w zakładzie karnym, prowadzących często do ciężkiego inwalidztwa) wymaga zastosowania postępowania leczniczego i rehabilitacyjnego, w tym przeprowadzenia rehabilitacji zawodowej umożliwiającej osobie pełnienie pozytywnej społecznie roli zawodowej.

Zadaniem wychowawcy jest określenie, czy podopieczny ze względu na stopień dysfunkcji o podłożu somatycznym lub organicznym wymaga zastosowania określonych jakościowo oddziaływań, oraz ułatwienie mu dotarcia do tego rodzaju pomocy. Funkcje pośredniczące $\mathrm{w}$ tym procesie pełnią agencje pomocy postpenitencjarnej dysponujące wykazem wyspecjalizowanych placówek pomocowych. Zabiegi terapeutyczne świadczone są przez wyspecjalizowane ośrodki i zakłady pomocowe niezależnie od oddziaływania resocjalizacyjnego.

Kliniczny model oddziaływań resocjalizacyjnych zawiera zabiegi korekcyjne umożliwiające wypełnienie funkcji wychowawczych i terapeutycznych. W praktyce pracy poprawczej często niezbędne jest umieszczenie osoby w specjalistycznym zakładzie lub ośrodku pomocowym. Narzędziem opiekuna służącym osiągnięciu tego celu postępowania resocjalizacyjnego jest skierowanie jednostki do odpowiedniej placówki opieki postpenitencjarnej. 
W przypadku działalności resocjalizacyjnej w terenie (poza instytucjami pomocowymi) oddziaływanie wychowawcze ukierunkowane jest na fazę postępowania przed skierowaniem do placówki specjalistycznej oraz na fazę po powrocie skazanego z zakładu leczniczego. Natomiast opiekun pracujący z przypadkiem w instytucji pomocowej kieruje swe zasadnicze oddziaływanie na etap postępowania w czasie skierowania.

Na każdym z etapów procesu resocjalizacji wychowawca stanowi oś trójstronnej interakcji między osobą, jej środowiskiem rodzinnym i instytucją świadczącą na jej rzecz specjalistyczną pomoc (Biestek 1997, s. 273).

Na pierwszym etapie oddziaływani wychowawczego (przed skierowaniem do placówki specjalistycznej) opiekun musi pomóc podopiecznemu w rozwiązywaniu problemów skupiających się najczęściej wokół:

1) Obaw i stanów lękowych związanych z ewentualnym ograniczeniem niezależności w czasie przebywania w specjalistycznej instytucji pomocowej. Obawy te wypływają z faktu, że podopieczny przebywał przed procesem resocjalizacyjnym w zakładzie karnym. Dolegliwość zastosowanej wobec niego sankcji za popełnione przestępstwo polegała w głównej mierze na pozbawieniu go prawa do wolności.

2) Braku poczucia bezpieczeństwa, powstającego najczęściej z obawy przed nową sytuacją, w jakiej się znajdzie osoba, nieznanymi wcześniej procedurami instytucjonalnymi i metodami oddziaływania, jak również z lęku przed kontaktami środowiskowymi.

3) Poczucia winy osoby resocjalizowanej. Jednostka może obwiniać siebie za spowodowanie okoliczności uzasadniających skierowanie do instytucji pomocowej.

4) Władzy. Wszelkie instytucje są postrzegane przez osoby (zresztą często zgodnie z prawdą) jako struktury społeczne posiadające restrykcyjny system oddziaływania władczego. Sceptycyzm w postrzeganiu instytucji społecznych przez więźniów pogłębiony jest ich własnymi doświadczeniami wyniesionymi z zakładu penitencjarnego podczas odbywania kary pozbawienia wolności. Skazani doświadczali negatywnych form oddziaływania aparatu więziennego, ale również patologicznej przemocy ze strony subkultury więziennej. Odczucia jednostki związane z podejmowanymi wobec niej w czasie leczenia władczymi formami oddziaływania mogą stanowić reminiscencje negatywnych doświadczeń wyniesionych z zakładu karnego. Najczęściej wyrażają się one w świadomym bądź nieświadomym antagonizmie wobec oddziaływań specjalistycznych, uległości lub agresji wobec otoczenia. Wcześniejsze doświadczenia mogą 
stanowić również przesłankę do dokonania przez osobę oceny przyczyn, które spowodowały głębokie zaburzenia w jej osobowości.

5) Obaw i związanego z nimi niepokoju więźnia, czy rodzina zaakceptuje go po pobycie w instytucji pomocowej.

6) Lęku, że okres przebywania osoby w zamkniętym zakładzie leczniczym spowoduje utratę osiągniętych postępów w jej readaptacji społecznej.

7) Niepewności, czy podejmowane zabiegi specjalistyczne nie spowodują dalszego ograniczenia możliwości samodzielnego rozwiązywania istotnych spraw i problemów życiowych. Na przykład w następstwie niezbędnej ze względu na stan zdrowia interwencji specjalistycznej skazany może doznać trwałego ograniczenia sprawności fizycznej, utrudniającego po opuszczeniu instytucji znalezienie pracy i w związku z tym pełnienie roli zawodowej.

Reakcje rodziny w sytuacji, gdy osoba została umieszczona na pewien czas $\mathrm{w}$ instytucji pomocowej, mogą przybierać różne formy. Członkowie rodziny mogą z ulgą przyjąć fakt izolacji osoby jako okazji do pozbycia się ze swego grona nie akceptowanej osoby. Jednakże takie destruktywne zachowanie się środowiska rodzinnego nie jest zasadą. Członkowie grupy mogą wykazać zainteresowanie problemami osoby i odczuwać przykrość z powodu jej ponownej izolacji lub przynajmniej doznawać ambiwalentnych emocji z tym związanych.

Niezwykle ważne jest na tym etapie postępowania, aby rodzina skazanego umieszczonego w specjalistycznym zakładzie pomocowym znalazła w opiekunie wsparcie w tej trudnej sytuacji i aby osoba mogła na przykład uzyskać środki finansowe zabezpieczające jej funkcjonowanie. Zadaniem wychowawcy będzie zapewnienie rodzinie podopiecznego materialnych świadczeń pomocowych.

Jeśli chodzi o wzajemne interakcje opiekuna i instytucji pomocowej, to na tym etapie postępowania wychowawczego spoczywa na nim odpowiedzialność za:

1) wybór odpowiedniej instytucji specjalistycznej opieki stosownie do potrzeb i charakteru zaburzeń w osobowości skazanego,

2) dotrzymanie poufności, jeśli przesłanką osiągnięcia celów tego etapu resocjalizacji jest zachowanie dyskrecji jego przebiegu,

3) przygotowanie instytucji opieki postpenitencjarnej na przyjęcie osoby wychowywanej do wolności (Blau, Scott 1993, s. 211).

Opiekun powinien dostarczyć wyznaczonemu personelowi zakładu czy ośrodka pomocowego raport dotyczący przebiegu oddziaływania terapeutycznego po opuszczeniu przez skazanego zakładu karnego. Raport taki powinien zawierać także ocenę sytuacji rodzinnej osoby, jej emocjonalnego nastawienia do skierowania i instytucji pomocowej. 
Jeśli skierowanie nie jest wynikiem nagłego załamania w osobowości skazanego, na przykład w sytuacji kryzysowej, opiekun powinien odpowiednio wcześniej: 1) dokładnie przedyskutować cele skierowania ze specjalistą mającym prowadzić pracę z podopiecznym, 2) przydzielić role i zadania stronom biorącym udział w socjalizacji jednostki, tj. rodzinie skazanego, instytucji świadczącej specjalistyczną pomoc, samemu skazanemu, a także uwzględnić swoją rolę.

$\mathrm{Na}$ etapie przed skierowaniem głównym celem resocjalizatora jest przygotowanie podopiecznego, jego rodziny i instytucji pomocowej do takiego współdziałania w czasie procesu, które pozwoliłoby na osiągnięcie celów skierowania. Podstawową metodą służącą osiągnięciu tych celów będzie poszerzanie wiedzy stron uczestniczących w skierowaniu na temat złożonego charakteru pracy z daną osobą (włączając w to, jeśli tylko byłoby to możliwe, wcześniejszy kontakt skazanego i jego rodziny z wybraną instytucją pomocową). Ponieważ na etapie skierowania mogą wystąpić, po każdej ze stron, zahamowania i blokady emocjonalne, opiekun powinien pomóc w ich przezwyciężeniu.

Podczas podejmowania decyzji o skierowaniu wychowawca będzie zmuszony analizować wszystkie aspekty - tak za skierowaniem, jak i przeciw. Powinien być pewny, że wybrał zgodny z potrzebami wychowawczymi danej osoby kierunek działania, a zaangażowana instytucja jest odpowiednia, kompetentna i zapewnia rzetelną opiekę nad pensjonariuszem.

Pozycja resocjalizatora na tym etapie postępowania poprawczego jest skomplikowana ze względu na zróżnicowane poparcie zainteresowanych stron, które może otrzymywać w związku z podjętą decyzją. Może ono wypływać tylko od jednej z nich (podopiecznego, rodziny czy instytucji - w tym przypadku wyrażane przez ich społecznych reprezentantów, na przykład lekarzy rejonowych czy rodzinnych, policjantów) lub wybranych dwóch przeciw trzeciej. Dotyczy to zarówno osoby, jak i instytucji pomocowej występujących przeciw rodzinie, rodziny i instytucji - przeciw podopiecznemu lub skazanego i rodziny - przeciw zakładowi specjalistycznej pomocy. Nie oznacza to tylko, że osoba poddana oddziaływaniom i jej rodzina są negatywnie usposobieni wobec ośrodka pomocy postpenitencjarnej, ale również, że placówka pomocowa może wstrzymać skierowanie, jeśli skazany i jego rodzina tego oczekują.

Oddziaływanie opiekuna na kolejnym etapie postępowania resocjalizacyjnego oparte jest na jego pozycji jako osoby, która nie wchodzi w skład hierarchii instytucji pomocowej i może wykorzystywać do celów wychowawczych więzi stworzone z rodziną podopiecznego. Jego działania mogą dotyczyć:

1) Pomocy w nawiązaniu poprawnych relacji między osobą a instytucją pomocową. Specjalistyczne oddziaływania ośrodka pomocowego mogą wywoływać w osobowości podopiecznego następujące doświadczenia: 
a) wzbogacające - które zapewniają osobie pozyskanie nowych możliwości rozwiązywania trudnych spraw i problemów życiowych, np. w efekcie podjętej rehabilitacji zawodowej osoba ta może osiągnąć przekwalifikowanie zawodowe. Oddziaływanie oświatowe podnosi poziom wykształcenia, dobry kontakt z personelem ośrodka pomocowego wpływa na pozytywne doświadczenia w stosunkach interpersonalnych $\mathrm{z}$ innymi, a oddziaływania terapeutyczne pomagają podopiecznemu w osiąganiu wyższego stopnia samoświadomości i samorealizacji.

Celem resocjalizatora na tym etapie postępowania wychowawczego jest wspieranie tak rozumianego wzbogacenia osobowości podopiecznego przez zachęcanie go do podejmowania dalszych wysiłków, pochwałę osiągniętych rezultatów socjalizacji i uświadomienie ich znaczenia dla ogólnej sytuacji życiowej jednostki.

b) regresywne - oddziaływania specjalistyczne mogą wywoływać zbyt duże uzależnienie osoby od zakładu pomocowego. Objawia się ono egocentryzmem jednostki, ciągłym uskarżaniem się na dolegliwości psychosomatyczne, nieodpowiedzialnym zachowaniem oraz buntem wobec wszelkich przejawów życia społecznego docierających z zewnątrz zakładu pomocowego.

W takich okolicznościach wychowawca powinien poddać problemy podopiecznego oddziaływaniu terapeutycznemu lub zapewnić taki rodzaj więzi łączących go z osobą, aby zespalający je związek wychowawczy stanowił efektywną pomoc i wsparcie eliminujące potrzebę zachowań regresywnych.

c) wywołujące dysfunkcje postaw i zachowań skazanego - osoba poddana oddziaływaniom może czuć się w klinice specjalistycznej odizolowana od otoczenia społecznego. Stan izolacji powoduje frustracje emocjonalne, agresję wobec procesów oddziaływań podejmowanych w ramach instytucji, uczucie skrępowania. Często człowiek taki może czuć się poniżony i niezrozumiany przez personel. Relacje takie prowadzą do natężenia problemów więźnia związanych z przebiegiem socjalizacji, a w krytycznej sytuacji mogą być przyczyną negacji celów, do których osiągnięcia zmierza proces readaptacji społecznej.

Podobnie jak w przypadku wystąpienia w osobowości skazanego stanów regresywnych, tak i w tej sytuacji opiekun powinien zmotywować podopiecznego do określenia głównych problemów i związanych z nimi odczuć emocjonalnych. Następnie poddać je oddziaływaniu terapeutycznemu, które doprowadzi do pozytywnej 
modyfikacji związku łączącego obydwa podmioty celem skuteczniejszego wychowywania skazanego do wolności.

2) Pomocy w utrzymaniu poprawnych relacji rodzinnych. Pomoc ta jest ukierunkowana na problemy:

a) bieżące, wypływające $\mathrm{z}$ faktu, że osoba poddana izolacji w klinice specjalistycznej nie jest zorientowana, jak kształtuje się rzeczywista sytuacja rodziny pod jej nieobecność,

b) przyszłe, związane $\mathrm{z}$ powrotem do środowiska rodzinnego po terapii w klinice specjalistycznej.

Będą one dotyczyły ponownego przejęcia ról w rodzinie. Jeżeli w wyniku niezbędnych zabiegów specjalistycznych została obniżona psychosomatyczna sprawność osoby, będzie ona musiała zaakceptować tę niekorzystną dla niej zmianę i nauczyć się poprawnie funkcjonować w otoczeniu społecznym z posiadanymi ułomnościami.

3) Pomocy w ponownej analizie problemów życiowych skazanego występujących przed skierowaniem.

Podczas ostatniego etapu kryzysu w czasie skierowania mogą ujawnić się w zachowaniu podopiecznego mechanizmy obronne. W tej sytuacji skazany, rozpatrując powody skierowania, dokonuje ich projekcji na otoczenie społeczne, obarczając je winą za fakt izolacji w zakładzie pomocowym. Mechanizmy te ulegają wzmocnieniu, jeżeli doświadczenia więźnia wypływające z interakcji z instytucją są negatywne. W tych okolicznościach wychowawcy pozostaje jedynie ukrycie przed osobą istoty wcześniejszych problemów stanowiących przyczynę skierowania. Ich ujawnienie bowiem spowodowałoby pogłębienie negatywnych doświadczeń związanych z izolacją, a w efekcie prowadziłoby to do odtrącenia przez jednostkę celów procesu adaptacji do warunków wolnościowych.

Podczas pobytu więźnia w specjalistycznej klinice pomocowej opiekun powinien również oddziaływać wychowawczo na jego rodzinę. Pracę resocjalizacyjną z rodziną skazanego podczas skierowania można podzielić na trzy etapy:

1) Wspólne (opiekuna i rodziny skazanego) rozwiązywanie problemów powstałych w związku ze skierowaniem jednostki do specjalistycznej instytucji pomocowej. Dotyczą one trudności z utrzymaniem pozytywnych kontaktów z izolowaną osobą, jak również z zapewnieniem wsparcia i pomocy dla rodziny ze strony jej najbliższego środowiska, np. sąsiedzkiego, grupy koleżeńskiej lub towarzyskiej. Uzyskanie pomocy służb socjalnych (tam, gdzie jest ona dostępna) pochłania zwykle dużo czasu, zanim stanie się ona osiągalna. Problemy te mogą być szczególnie dotkliwe, kiedy objęte jest skierowaniem jedno z rodziców i rodzina staje się przez to niepełna. 
Pauline Morris i Dennis Marsden naświetlają w swoich badaniach trudności żon i matek osób izolowanych, osamotnionych w biedzie, pozbawionych pomocy męża w opiece i kontroli nad dziećmi, i wynikającej stąd konieczności sprawowania podwójnej roli (matki i ojca) (Hollis 1992; Morris 1995, s. 192; Marsden 1969, s. 117). W takich okolicznościach odczuwane symptomy stresu, zmęczenia oraz pojawiające się depresje i załamania nerwowe są częstymi zjawiskami.

Nina Toren w swojej pracy (2002, s. 119) przywołuje badania nad problemami osamotnionego męża, który na skutek izolacji żony samotnie wychowuje dzieci. Jest on zmuszony godzić pracę zawodową z opieką nad dziećmi, a kiedy okazuje się to niemożliwe, staje wobec decyzji o porzuceniu pracy, co powoduje zmniejszenie dochodów i powstanie nowych problemów związanych z zapewnieniem bytu rodzinie.

$\mathrm{W}$ rodzinie podopiecznego umieszczonego w klinice specjalistycznej mogą również występować niepokoje o los izolowanego członka grupy, jak również obawy związane $\mathrm{z}$ jego ponownym przyjęciem po powrocie $z$ instytucji pomocowej.

2) Pomoc w rozwiązywaniu problemów istniejących jeszcze przed izolacją osoby:

a) bezpośrednio związanych ze skierowaniem, m. in. konieczność umieszczenia członka rodziny osoby izolowanej w ośrodku przystosowawczym,

b) pośrednio związanych ze skierowaniem, np. izolacja w zakładzie karnym członka rodziny skazanego przebywającego w klinice specjalistycznej, stanowiąca sankcję za popełnione przestępstwa w celu uzyskania środków finansowych dla zabezpieczenia bytu rodziny,

c) niezwiązanych ze skierowaniem, $\mathrm{m}$. in. hospitalizacja żony osoby izolowanej wskutek nagłego wypadku.

Skierowanie może stanowić o podniesieniu motywacji rodziny do rozwiązywania wcześniej istniejących problemów w readaptacji skazanego. Jednym z czynników wpływających na możliwość rozpoznania tych trudności przez opiekuna jest istnienie związku przyczynowego między skierowaniem a wcześniej istniejącymi problemami. Mogą one zostać uzupełnione poczuciem odpowiedzialności członków rodziny za los podopiecznego.

3) Pomoc opiekuna w nawiązaniu poprawnych stosunków między rodziną osoby poddanej próbie a specjalistyczną instytucją opieki.

Stosunek emocjonalny członków rodziny osoby izolowanej w klinice specjalistycznej może przybierać formy: pozytywne, negatywne lub 
ambiwalentne (relatywne). Postawy negatywne lub pozytywne są modyfikowane w czasie procesu oddziaływania specjalistycznego, dlatego w praktyce pracy pomocowej wychowawca najczęściej ma do czynienia z zachowaniami ambiwalentnymi. Jeżeli powodują one dysfunkcjonalne interakcje w rodzinie jednostki podlegającej skierowaniu, powodują zaburzenia w kontaktach z personelem instytucji pomocowej lub wywierają negatywny wpływ na postępy w leczeniu osoby izolowanej, wymaga to podjęcia przez opiekuna oddziaływania terapeutycznego.

Jako osoba pozostająca w kontakcie zarówno z podopiecznym, instytucją specjalistycznej opieki, jak i rodziną skazanego resocjalizator może świadczyć nieocenioną pomoc na tym etapie postępowania poprawczego. W pracy z instytucją opiekun może obserwowaćć z jej personelem postępy, jakie czyni osoba poddana specjalistycznemu oddziaływaniu. W wyniku analizy następuje modyfikacja pierwotnej diagnozy i celów, a także planów oraz metod oddziaływania poprawczego. $\mathrm{Na}$ każdym etapie postępowania specjalistycznego istotne znaczenie mają wnioski terapeutyczne wychowawcy wyniesione $\mathrm{z}$ wcześniejszej pracy z podopiecznym.

Informacje na temat sytuacji rodzinnej mogą wzbogacić wiedzę opiekuna o jednostce izolowanej, co ma wpływ na ocenę jej zachowania i postaw w czasie leczenia. Istotne znaczenie mają też dane o postawach członków rodziny skazanego wobec zakładu pomocy postpenitencjarnej, ponieważ wpływają one na sposób zachowania osoby dozorowanej podczas terapii specjalistycznej.

Również analiza interakcji między rodziną podopiecznego a personelem ośrodka pomocowego posiada istotne znaczenie, jako że rodzina będzie miała kontakt zarówno z wychowawcą, jak i z personelem instytucji. Wnioski z tej analizy mogą stanowić przesłankę do modyfikacji pierwotnego podziału ról pełnionych w czasie terapii specjalistycznej. Dla jej powodzenia niezbędne jest bowiem istnienie pozytywnej i wewnętrznie spójnej pracy grupowej z przypadkiem.

Ostatni etap postępowania poprawczego to rehabilitacja osoby i przystosowanie jej do warunków otoczenia społecznego, od którego była odizolowana podczas skierowania. Rzetelna praca resocjalizatora podczas etapu drugiego nad osiągnięciem jego celów zminimalizuje problemy mogące pojawić się w czasie oddziaływania przystosowawczego.

Po powrocie osoby izolowanej ze specjalistycznego zakładu opieki postpenitencjarnej zwykle następuje faza minimalizowania przez skazanego problemów związanych z jego readaptacją społeczną. Jednocześnie motywacja osoby wychowywanej do podjęcia działań zmierzających w kierunku ich rozwiązania ulega obniżeniu.

Możliwość podjęcia działań poprawczych zależy od następujących okoliczności:

a) czy mają one wpływ (bezpośredni lub pośredni) na skierowanie, czy tė̇ takiego nie posiadają, 
b) czy izolacja w specjalistycznej instytucji pomocy postpenitencjarnej pomogła, czy przeszkodziła w osiągnięciu celów postępowania resocjalizacyjnego,

c) czy skierowanie zwiększyło motywację osoby resocjalizowanej do podjęcia działań poprawczych (Wootton 2001, s. 52).

Praktyka działalności resocjalizacyjnej wskazuje, że po powrocie skazanego z izolacji w instytucji pomocowej wcześniejsze problemy powracają niezwykle szybko. Są one najczęściej związane z niemożnością znalezienia pracy, powrotami do nałogu, alkoholizmu i wykolejenia obyczajowego. Okoliczności takie sprzyjają powrotowi skazanego do przestępstwa. Wydawać się wtedy może, że oddziaływanie instytucjonalne okazało się nieskuteczne. Prawdą jest też, że często są to oznaki zaburzenia osobowości więźnia trudnego do wyleczenia.

Ponieważ nigdy jednak nie da się do końca poznać istoty tak skomplikowanej jak człowiek oraz przewidzieć wszystkich czynników interweniujących, nie należy generalizować, i w tym przypadku, przesłanek powodzenia socjalizacji skazanego. Po zwolnieniu ze skierowania osoba może nadal pozostawać w kontakcie ze specjalistyczną instytucją pomocy postpenitencjarnej. Taka sytuacja zobowiązuje również opiekuna do utrzymywania związku z personelem zakładu pomocowego.

O powodzeniu oddziaływania specjalistycznego (klinicznego) decyduje sposób, $\mathrm{w}$ jaki zostało ono odebrane $\mathrm{w}$ sensie emocjonalnym przez osobę izolowaną. Jeżeli wyniesione doświadczenia są głęboko negatywne, to najczęściej kontakt z wychowawcą zostaje przez skazanego zerwany. Opiekun jest bowiem postrzegany jako pracownik instytucji, z którą wiąże negatywne wspomnienia i o której chciałaby jak najszybciej zapomnieć. Jednak i w takich okolicznościach resocjalizator może wykorzystać niechęć skazanego zmierzającą do powrotu do specjalistycznej kliniki. Przedstawiając podopiecznemu możliwości uniknięcia takiej sytuacji, łatwiej już będzie opiekunowi wykorzystać jego motywację do działań resocjalizacyjnych.

Współdziałanie wychowawcy, prowadzącego terenową pracę w warunkach resocjalizacji, z personelem specjalistycznym instytucji pomocowych jest $\mathrm{z}$ reguły niewystarczające do osiągnięcia sprawnego współdziałania grupowego w tym procesie. Wydaje się, że powodem takiej sytuacji mogą być następujące czynniki:

1) różnice strukturalne między specjalistycznymi zakładami pomocy postpenitencjarnej. Każda instytucja posiada odmienną hierarchię, różne systemy komunikacji, procedury, metody i środki oddziaływania terapeutycznego, cele działalności oraz zróżnicowane środki finansowe, którymi dysponuje;

2) komunikacja między instytucjami pomocowymi, jak również między nimi a opiekunami pracującymi w terenie jest bardzo osłabiona $\mathrm{z}$ powodu 
odmienności celów i metod działania oraz często wysokiego stopnia biurokratyzacji zakładów pomocowych;

3) status uprawniający do podjęcia oddziaływania terapeutycznego. Ośrodki pomocowe prowadzą działalność terapeutyczną na podstawie ściśle sformalizowanych procedur, podczas gdy wychowawca pracujący z podopiecznym na podstawie upoważnienia ustawowego ma w tym zakresie dużo większą swobodę.

Praktyka pracy resocjalizacyjnej wykazuje, że w fazie obejmującej trzy etapy skierowania osoby do specjalistycznej instytucji pomocowej zarówno ona, jak i jej najbliższe środowisko społeczne (rodzinne, sąsiedzkie, koleżeńskie) wykazują liczne potrzeby wychowawcze. Stanowią one obszar pracy pomocowej terenowych resocjalizatorów. Jednakże w praktyce praca ta jest rzadko podejmowana. Często opiekun postrzega skierowanie jako koniec pracy z wychowankiem, jeżeli nie w ogóle, to przynajmniej do czasu zwolnienia jednostki z izolacji. Jednak znaczenie ciągłości pracy po skierowaniu, choćby tylko w celu utrzymania żywych i pozytywnych więzi między nim i podopiecznym jest oczywiste dla sukcesu oddziaływania resocjalizacyjnego. Zaprzestanie oddziaływania na jednostkę w czasie etapu skierowania jest niekorzystne dla osiągnięcia celów specjalistycznego oddziaływania terapeutycznego (klinicznego). Może być także odbierane przez osobę oraz jej rodzinę jako odrzucenie.

Zastanawiająca jest również mała częstotliwość skierowań osób do specjalistycznych zakładów pomocowych. Dla przykładu można podać, że spośród skazanych, u których stwierdzono daleko posunięty alkoholizm, połączony często z degradacją alkoholową jednostki, zaledwie 10\% skierowanych zostało na leczenie odwykowe (Anderson, Bamberg 2007, s. 320).

\section{KOMUNIKACJA SPOŁECZNA OD KSZTAŁTOWANIA SUMIENIA DO PSYCHOMANIPULACJI}

Spotkanie i dialog w procesie komunikacji społecznej zmierzać może do kształtowania sumienia jednostki oraz psychospołecznych relacji między uczestnikami życia zbiorowego. Podstawowym wyznacznikiem tożsamościowego modelu wychowywania jest podmiotowe traktowanie osoby. Zgodnie z koncepcją Ewy Starczewskiej w resocjalizacji oznacza to, iż jednostka zawsze jest postrzegana jako autonomiczny podmiot, a nie przedmiot manipulacji, jest ona twórcą samego siebie, istotą zdolną do rozwoju i samodzielnego odkrywania sensu swych doświadczeń (Starczewska 2003, s. 72). 
Podmiotowe odbieranie człowieka w interakcjach społecznych oznacza uznawanie jednostki za wartość autonomiczną tzn. taką, w której istocie tkwi atrybut wartościowości bez względu na to, czy ludzie tak ją traktują, czy nie. Ponadto nie poddaje się relatywizacji względem wartościujących przeżyć i poświadcza się wagę odrębności oraz indywidualności każdego człowieka bez względu na to, jak oceniamy jego czyn czy zachowanie i w jakim stopniu są one dezaprobowane (Gogacz 1985, s. 117).

Odwrotnym układem społecznym modelowanym przez cyberprzestrzeń jest instrumentalne traktowanie jednostki. W tym ujęciu osoba nie jest wartością autonomiczną, lecz jedynie rzeczą i może być oceniana wyłącznie za swą przydatność do realizacji celów wobec niej nadrzędnych, które wyznaczają interes zorganizowanej zbiorowości. Tym samym człowiek nie jest sam w sobie celem, lecz tylko środkiem do celu. Utożsamiany jest niemal bez reszty z rolą, którą wyznacza mu system organizacji zbiorowości, i oceniany wyłącznie ze względu na to, jak rolę wypełnia.

W procesie komunikacji resocjalizacyjnej - w tej koncepcji - jednostka jest istotą sterowaną z zewnątrz i całkowicie zdeterminowaną przez warunki, w których żyje. Może być także obiektem dowolnej manipulacji, traktowana jak materiał, który daje się ukształtować czy wymodelować przy pomocy represji, behawioralnego warunkowania czy też złożonych zabiegów oddziaływania zewnętrznego opartego na znajomości obiektywnych procesów psychicznych osoby (Gogacz 1992, s. 73).

Psychomanipulacja jest szczególną postacią wywierania wpływu i nacisku na jednostki. Różni się ona od edukacji, wychowania, terapii czy zróżnicowanych treningów rozwojowych tym, że traktuje osobę jako przedmiot i środek służący do dowolnego modelowania.

Zdaniem Adama Podgóreckiego manipulacje to różnorodne sposoby oddziaływania na jednostkę lub grupę, które zmierzają do mylnego przekonania u osoby manipulowanej, że jest sprawcą jakiegoś zachowania, podczas gdy jest ona narzędziem w rękach rzeczywistego sprawcy (Podgórecki 1976, s. 59).

Natomiast Ryszard Nawrat uważa, iż „manipulacja polega na włamaniu się do umysłu jakiejś osoby w celu wprowadzenia doń opinii bądź spowodowania zachowania w taki sposób, że osoba manipulowana nie zdaje sobie sprawy z tego, że nastąpiło to włamanie" (Nawrat 1989, s. 125).

Istotę zjawiska oddaje definicja Elżbiety Zdankiewicz-Ścigały określająca psychomanipulację jako proces polegający na zastosowaniu ograniczenia niezależności odbiorcy w sposób dla niego niewidoczny i przez niego niekontrolowany, czyli w efekcie na wprowadzeniu owego odbiorcy w błąd i świat zakłamania (Zdankiewicz-Ścigała 2003, s. 275). Tym samym uznać można, iż psychomanipulacja to proces wywoływania chwilowych lub trwałych zmian w zachowaniu i postawach jednostek za pomocą skrywanych i podstępnie wykorzystanych psychologicznych 
metod wywierania wpływu, najczęściej w formie deformujących rzeczywistość społeczną komunikatów werbalnych oddziałujących na uczucia, emocje i motywacje osób w celu uzależnienia ich od interesów własnych nadawców tychże komunikatów.

Mechanizmy, które wyzwalają procesy pozwalające na kontrolowanie myśli jednostek, sterowanie emocjami lub ich działaniami należy definiować jako zabiegi manipulacyjne. Jest to zatem forma zamierzonego wywierania wpływu na osobę lub grupę w taki sposób, aby wbrew świadomości i woli odbiorców działania te zaspakajały potrzeby manipulatora. Ta gra dotyczyć może treści lub sposobu przekazywania komunikatów. Natomiast psychomanipulacja jest pojęciem o zakresie znaczeniowym węższym i dotyczy mechanizmów wywierania wpływu przez wykorzystywanie reguł psychologicznych odpowiedzialnych za przebieg ludzkiego postępowania.

Instrumentalne i przedmiotowe odbieranie jednostki w procesach interaktywnych sprowadza się do wywierania wpływu na osobę w taki sposób, aby nie zdawała sobie ona sprawy z tego, że podlega jakimkolwiek oddziaływaniom, bądź by nie była świadoma siły lub konsekwencji tych procesów. Podstawowym motywem postępowania osoby posługującej się manipulacją społeczną jest maksymalizacja własnego interesu albo interesu grupy bądź instytucji, z którą się w pełni identyfikuje (Doliński 2000, s. 505).

Manipulowanie w komunikacji międzyludzkiej zachodzi wszędzie tam, gdzie zdaniem osoby manipulującej nastąpiłaby rozbieżność między akceptowanym wzorem zachowania osoby będącej przedmiotem manipulacji a podsuwanym mu wzorem zachowania, gdyby wykonawca nie został w jakiś sposób ograniczony w swej decyzji. Właśnie to ograniczenie decyzji wykonawcy jest przedmiotowym traktowaniem jednostki. Manipulacja to zatem wszelkie sposoby komunikowania się z jednostką lub grupą, które prowadzą do mylnego przekonania u osoby manipulowanej, że jest ona sprawcą jakiegoś zachowania, podczas gdy jest ona narzędziem w rękach rzeczywistego sprawcy (Podgórecki 1976, s. 117).

Proces spotkania i dialogu w resocjalizacji może przebiegać od bieguna sumienia do bieguna manipulacji społecznej. Wymiar sumienia ludzkiego kształtuje podejście oparte na paradygmacie tożsamości osobowej, społecznej i kulturowo-cywilizacyjnej, zaś manipulacja odbywa się za pośrednictwem sterowania i socjotechniki wspartej na instrumentalnym traktowaniu osoby.

Resocjalizacja jako proces humanizowania relacji społecznych może odbywać się wyłącznie przy zaakceptowaniu zasad etyki, chroniących osoby przed dowolnością, relatywizmem i subiektywnymi ideałami podmiotów oddziaływujących na jednostkę. 


\section{LITERATURA}

Anderson P., Bamberg B., 2007, Alkohol w Europie. Raport zperspektywy zdrowia publicznego. Warszawa, Wydawnictwo Edukacyjne Parpamedia.

Bałandynowicz A., 2011, Reintegracja społeczna skazanych. Paradygmat tożsamości osobowej, społecznej i kulturowo-cywilizacyjnej. „Resocjalizacja Polaka”, nr 2.

Baran B., 1992, Filozofia dialogu. Kraków, Wydawnictwo Znak.

Bartol C.R., 2005, Criminal Behavior: A Psychosocial Approach. New Jersey, Prentice Hall.

Bell J.E., 1999, Family Group. New York, Bookstall Publications.

Bernstein B., 1991, Class, Codes and Control. New York, Routledge and Kegan Paul. Biestek F.P.,1997, The Casework Relationship. Londyn, George Allen and Unwin.

Blau P.M., Scott W.R., 1993, Formal Organisations. Londyn, Routledge and Kegan Paul.

Buber M., 1992, Ja i Ty. Wybór pism filozoficznych. Warszawa, Instytut Wydawniczy PAX.

Caplan G., 1994, Principles of Preventive Psychiatry. New York, Tavistock.

Chałas K., 2003, Wychowanie ku wartościom. Elementy teorii i praktyki. Godność, wolność, odpowiedzialności, tolerancji. Lublin-Kielce, Wydawnictwo Jedność.

Conklin J.E., 1992, Robbery and the criminal justice system. Philadelphia, Lippincott.

Deutschmann L.B., 2001, Deviance and control. Toronto, ITP. Nelson.

Dolan M., 2004, Psychopathic personality in young people. "Advances in Psychiatric Treatment", nr 10, 460.

Doliński D., 2000, Inni ludzie w procesach motywacyjnych. W: J. Strelau, Psychologia ogólna. Gdańsk, Gdańskie Wydawnictwo Psychologiczne.

Fromm E., 2000, Niech się stanie człowiek. Kraków, Wydawnictwo Znak.

Gałdowa A., 2000, Powszechność i wyjątek. Rozwój osobowości człowieka dorosłego. Kraków.

George V., Wilding I., 1992, Motherless Families. Londyn, Routledge and Kegan Paul.

Gogacz M., 1985, Człowiek i jego relacje. Warszawa, Wydawnictwo ATK.

Gogacz M., 1992, Światopogląd afirmujący Boga. W: B. Bejze (red.), O filozoficznym poznaniu Boga dziś. Studia z filozofii Boga, t. V. Warszawa, Wydawnictwo ATK.

Goldberg E.M., 1991, The Normal Family: myth and reality in Social Work with Families. New York, George Allen and Unwin.

Halbwachs M., 1969, Społeczne normy pamięci. Warszawa, PWN.

Hollis F., 1992, Casework: a Psycho - Social Therapy. Londyn, George Allen and Unwin. 
James R.K., Gilland B.E., 2009, Strategie interwencji kryzysowej. Warszawa, Wydawnictwo PARPA.

Jan Paweł II, 2004a, Pamięć i tożsamość. Kraków, Wydawnictwo Żak.

Jan Paweł II, 2004b, Przekroczyć prób nadziei. Kraków, Wydawnictwo Znak.

Jordan W., 1992, The Social Worker in Family. Situation's. Londyn, Routledge and Kegan Paul.

Kieszkowska A., 2012, Inkluzyjno-katalaktyczny model reintegracji społecznej skaznaych. Konteksty resocjalizacyjne. Kraków, Oficyna Wydfawnicza Impuls.

Konopczyńki M., Ambrozik W. (red.), 2009, Współczesne kierunki zmian w teorii i praktyce resocjalizacyjnej. Warszawa, Wydawnictwo CMPPP.

Konopczyński M., 2009a, Kierunki zmian w teorii i praktyce resocjalizacyjnej. „Pedagogika Społeczna”, nr 2.

Konopczyński M., 2009b, Twórcza resocjalizacja - od korekcji do rozwoju. W: A. Rejzner, P. Szczepanik (red.), Terapia $w$ resocjalizacji. Część I. Ujęcie terapeutyczne. Warszawa, PWN.

Konopczyński M., 1996, Twórcza resocjalizacja. Wybrane metody pomocy dzieciom i młodzieży. Warszawa, MEN.

Mader J., 1989, Filozofia dialogu. W: J. Tischner (red.), Filozofia współczesna. Kraków, Instytut Teologiczny Księży Misjonarzy.

Malewska A., 1962, Pozytywny i negatywny obraz własnej osoby w proces podejmowania decyzji. „Studia Socjologiczne”, nr 2.

Marsden D., 1969, Mothers Alone. London, Penguin Press.

Morris P., 1995, Prisoners and their Families. Londyn, George Allen and Unwin.

Nawrat R., 1989, Manipulacja społeczna - przegląd technik i wybranych wyników badań. „Przegląd Psychologiczny”, tom 32.

Opoczyńska M., 2004, Wprowadzenie do psychologii egzystencjalnej. Kraków

Pasamonik B., 1999, Tożsamość osobowa. Kraków, Wydawnictwo Znak.

Pettigrew T.F., 1998, Intergroup Contact Theory. „Annual Review of Psychology”, nr 1.

Podgórecki A., 1976, Zasady socjotechniki. Warszaw, Czytelnik.

Pospiszyl I., 2008, Patologie społeczne. Warszawa, PWN.

Pytka L., 1995, Granice kontroli społecznej i autonomii osobistej młodzieży. „Opieka - Wychowanie - Terapia”, nr 1/212.

Reid W.J., Shyne A.W., 1997, Brief and Extended Casework. New York, Columbia University Press.

Sobczak S., 2004, Aksjologiczne wątki w koncepcji samoświadomości Zbigniewa Zaborowskiego. W: L. Pytka, T. Rudowski (red.), Samoświadomość i jakość życia. Perspektywa psychospołeczna. Warszawa, Eneteia - Wydawnictwo Psychologii i Kultury. 
Starczewska E., 2003, Koncepcja człowieka a model wychowania, Warszawa, PWN. Steinberg S., Bar-On D., 2002, An analysis of the group process in encounters between News and Palestinians using a typology for discourse classification. "International Journal of Intercultural Relations".

Szacka B., 2003, Pamięć zbiorowa i wojna. „Przegląd Socjologiczny”, nr 2.

Toren N., 2002, Social Work the Case of Semi-profession. New York.

Urban B., 2000, Zaburzenia w zachowaniu i przestępczość młodzieży. Kraków, Wydawnictwo UJ.

Willmott P., Young M., 2001, Family and Kinship in East London. London, George Allen and Unwin.

Wojtowicz M., 2005, Doświadczenie lęku egzystencjalnego jako sytuacja wyboru. Katowice, PWN.

Wootton B., 2001, Social Science and Social Pathology. Londyn, George Allen and Unwin.

Wysocka E., 2008, Diagnoza w resocjalizacji. Warszawa, PWN.

Zdankiewicz-Ścigała E., 2003, Inni ludzie w procesach motywacyjnych. W: J. Strelau (red.), Psychologia ogólna. Gdańsk, Gdańskie Wydawnictwo Psychologiczne.

\author{
INDIVIDUALISTIC AND SUPRA-INDIVIDUALISTIC PREDICTORS \\ OF OPTIMAL SOCIAL REHABILITATION IMPACT ON \\ OFFENDERS UNDER NON-CUSTODIAL SUPERVISION
}

\begin{abstract}
The meeting that reaches the boundaries of dialogical moments (dialogical i.e. reaching the depth in interpersonal communication) may be an identity-creative situation i.e. the situation in which the identity of participants is acted, learnt, and experienced. The most important conditions which enable us to make a full dialogue are: the kinds of relationships between participating parties, attention and mutual understanding, and love. Interpersonal relations differ in the number of participants, in their depth, character, intensity in time, and may signal the type of a meeting. In the context of philosophical anthropology of Teilhard de Chardin, B. Pasamonik presents the process of communication as a relation of utilitarian character, oriented towards achieving something, and as a personalist relation whose aim is to "meet somebody". In the latter, there is no clearly cognitive aim that would reduce "the Other" to the object of cognition; it is rather about the possibility of communing, being opened to another person, which is possible only in the case of a relationship based on responsibility.
\end{abstract}

Keywords: dialogue, meeting, dialogue in social rehabilitation, communication process, identity-creative situation, psycho-manipulation 